\title{
Productivity and Biochemical Characteristics of Sugarcane When Submitted to the Action of Chemical Ripeners
}

\author{
Ronaldo da Silva Viana ${ }^{1}$, Lucas Aparecido Manzani Lisboa ${ }^{1 ; 2}$, Paulo Alexandre Monteiro Figueiredo ${ }^{1}$, Sérgio \\ Bispo Ramos ${ }^{1}$, Samuel Ferrari ${ }^{1}$, André May $^{3}$, Evandro Pereira Prado ${ }^{1}$, Celso Tadao Miasaki ${ }^{1}$, Igor da Silva \\ Ferreira $^{2}$, Jeruska Azevedo Moreira Brenha ${ }^{2}$
}

${ }^{1}$ São Paulo State University (Unesp), College of Technology and Agricultural Sciences, Dracena, São Paulo, Brazil.
${ }^{2}$ Integrated College Stella Maris (FISMA) and Educational Fundation of Andradina (FEA), Andradina, São Paulo, Brazil.
${ }^{3}$ Brazilian Agricultural Research Corporation, EMBRAPA, Environment, Jaguariúna, São Paulo, Brazil.

Correspondence Author: Ronaldo da Silva Viana, São Paulo State University (Unesp), College of Technology and Agricultural Sciences, Dracena, São Paulo, Brazil.

E-mail:- ronaldo.viana@unesp.br

Received date: 10 January 2019, Accepted date: 25 February 2018, Online date: 28 February 2019

Copyright: ( 2019 Ronaldo da Silva Viana et al, This is an open-access article distributed under the terms of the Creative Commons Attribution License, which permits unrestricted use, distribution, and reproduction in any medium, provided the original author and source are credited.

\begin{abstract}
The utilization of chemical ripeners is an important tool, since they are applied to accelerate the maturation process, enhance raw material quality, optimize agro industrial and economic results, and help crop planning, allowing essential crop management in a modern production system. The objective of this study was to evaluate agricultural productivity and biochemical characteristics of the sugarcane when submitted to the application of chemical ripeners in different crop years. The experimental design utilized randomized blocks arranged in split split plots. The main plots consisted of the application of the following products with their respective doses: control (C) (without application), sulfomethuron-methyl (0.02 kg ha-1) + glyphosate (0.15 L ha-1) (SG), ethephon $\left(0.34 \mathrm{~L} \mathrm{~h}^{-1}\right)$ + glyphosate $\left(0.15 \mathrm{~L} \mathrm{ha}^{-1}\right)(\mathrm{EG})$, glyphosate $\left(0.35 \mathrm{~L} \mathrm{~h}^{-1}\right)(\mathrm{G})$, compounds of organic carboxylic radicals $\left(1.0 \mathrm{~L} \mathrm{~h}^{-1}\right)$ + glyphosate (0.15 $\left.\mathrm{L} \mathrm{h}^{-1}\right)(\mathrm{CG})$. The subplots were composed of evaluation times: 0, 15, and 30 days after application of the products. The sub-subplots consisted of two crop years, 2008 and 2009. In the evaluations, the levels of brix levels, pol, reducing sugars, total reducing sugars, fiber, purity, humidity, recoverable theoretical sugar, tons of Culms per hectare and tons of sugar per hectare, shikimic and salicylic acids. The application of CG showed better

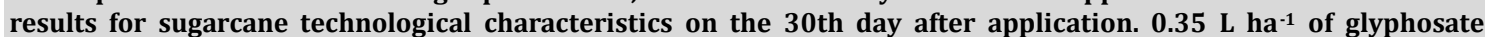
favored an increase in the concentrations of shikimic and salicylic acids. The application of a mixture of compounds of organic carboxylic radicals + glyphosate presented better results for sugarcane technological characteristics at 30 days after application in the studied crop years. The application of $0.35 \mathrm{~L} \mathrm{ha}^{-1}$ glyphosate favored an increase in the concentrations of shikimic and salicylic acids in the crop years of 2008 and 2009.
\end{abstract}

Keywords: growing, hormones, plant regulators, Saccharum spp.

\section{INTRODUCTION}

Sugarcane (Saccharum spp.) is native to southeastern Asia and has been cultivated in Brazil since the $16^{\text {th }}$ century. Nowadays, due to plant breeding, several varieties have been developed and adapted to different climatic conditions, soils, and so on (CAPUTO et al., 2007).

Although presently there is a diverse availability of Poaceae varieties, sucrose levels from these materials are not always able to guarantee the yield expected by sugar-energy industry, and, therefore, many times chemical substances are applied to optimize results (SILVA et al., 2010).

Thus, the utilization of chemical ripeners is an important tool, since they are applied to accelerate the maturation process, enhance raw material quality, optimize agro-industrial and economic results, and help crop planning, allowing essential crop management in a modern production system ( VIANA et al., 2008; ROBERTO et al., 2015).

Chemical ripeners are compounds applied to the plant so that the correct dose can stop sugarcane vegetative development due to their inhibiting action on metabolism, causing maturation, that is, translocating and storing sugars in the stalks (LEITE et al., 2009a). 
Citation: Ronaldo da Silva Viana, et al., Productivity and Biochemical Characteristics of Sugarcane When Submitted to the Action of Chemical Ripeners. Australian Journal of Basic and Applied Sciences, 13(2): 64-71. DOI: 10.22587/ajbas.2019.13.2.9

Salicylic acid is the main signaling compound to develop plant resistance to pathogens and abiotic stresses and some pests as well. This acid is produced from phenylalanine, one out of three aromatic amino acids whose synthesis is blocked by glyphosate. The analysis of available information shows that for a plant to be resistant to biotrophic pathogens (that do not cause the death of parasitized cells such as viruses, rust, coal and others), it needs to produce and accumulate salicylic acid besides presenting the correct resistance genes.

Failure to produce this acid causes susceptibility which may be reverted by the exogenous compound application, showing the mistaken participation of salicylic acid as resistance inducer. Low doses of glyphosate can inhibit salicylic acid synthesis and increase plant susceptibility to diseases (MESCHEDE et al., 2012).

Therefore, this study aimed to evaluate the agricultural productivity and biochemical characteristics of sugarcane when submitted to the application of chemical ripeners at the beginning of different crop years.

\section{MATERIAL AND METHODS}

Experiments were carried out in 2008 and 2009 on Santo Antônio farm, located in the municipality of Igaraçu do Tietê, São Paulo state, at the following geographical coordinates: $22^{\circ} 33^{\prime} 18^{\prime}$ ' S latitude and $48^{\circ} 31^{\prime}$ 51' longitude, $509 \mathrm{~m}$ altitude.

The area primary production environment has semi-plain topography and its soil is eutroferric red latosol according to Embrapa (2013) classification. According to Köppen classification, the predominant climate in the region is Aw, dry, with an average yearly temperature of $21.6^{\circ} \mathrm{C}$ and average relative air humidity of $70 \%$. The average yearly rainfall is $1.344 \mathrm{~mm}, 2000$ $\mathrm{kg} \mathrm{ha}^{-1}$ of limestone and $600 \mathrm{~kg} \mathrm{ha}^{-1}$ of NPK 10-25-25 were applied to a sugarcane crop at planting in February 2007, following the technical recommendation in function of soil analysis. A dose of $1.2 \mathrm{~L} \mathrm{ha}^{-1}$ of Imidacloprid, an insecticide, was applied. The experiment was set up with cane plant in March 2008 and with ration cane in 2009, when chemical ripeners were applied on RB85-5156 variety at the beginning of the crop.

Each plot consisted of seven 10-m rows with 1.40-m spacing. The samples were collected from five central rows, totaling an area of $70 \mathrm{~m}^{2}$. The plots consisted of applications of the following products: C - control, that is, without application; SG sulfomethuron-methyl $\left(0.02 \mathrm{~kg} \mathrm{ha}^{-1}\right)+$ glyphosate $\left(0.15 \mathrm{~L} \mathrm{ha}^{-1}\right) ; \mathrm{EG}-$ ethephon $\left(0.34 \mathrm{~L} \mathrm{ha}^{-1}\right)+$ glyphosate $\left(0.15 \mathrm{~L} \mathrm{ha}{ }^{-1}\right) ; \mathrm{G}-$ glyphosate $\left(0.35 \mathrm{~L} \mathrm{ha}^{-1}\right) ; \mathrm{CG}-$ compounds of organic carboxylic radicals $\left(1.0 \mathrm{~L} \mathrm{ha}^{-1}\right)+$ glyphosate $\left(0.15 \mathrm{~L} \mathrm{ha}^{-1}\right)$.

The application of chemical ripeners was done with a $\mathrm{CO}_{2}$ - pressurized spraying equipment with 6-m T-shaped lance and 6 AXI 11002 nozzles, jet spaced $0.5 \mathrm{~m}$, which allowed the simultaneous application on two rows approximately $50 \mathrm{~cm}$ apart. The utilized pressure was 40 pounds inch ${ }^{-2}$, and juice volume was $300 \mathrm{~L} \mathrm{ha}^{-1}$. The application started at $8 \mathrm{~h} 00$ hours and finished at $11 \mathrm{~h} 00$ hours, a period in which little wind was observed. The average temperature varied from 25 to $30^{\circ} \mathrm{C}$ and with relative air humidity from 60 to $80 \%$. The subplots consisted of three sampling periods, 0,15 and 30 days after the application (daa) of products used as ripeners. The sub-subplots consisted of different crop years, 2008 and 2009.

At these times, sugarcane stalks were harvest by hand from a linear meter in the useful area of the plots. The stalks were clipped at the height of the apical buds, that is, at the breaking point and sent to the laboratory for analysis of the following characteristics: Brix (\% juice), pol (\% juice), reducing sugars (RS\%), total reducing sugars (TRS \%); fiber (\%), purity (\%), humidity (\%) and recoverable theoretical sugar (RTS) $\left(\mathrm{kg} \mathrm{t}^{-1}\right)$, according to the methods of chemical and technological determination by Consecana (2006). At harvest, the plots were completely harvested and the stalks were clipped for weighing and determination of Tons of Culms per Hectare (TCH) and Tons of Sugar per Hectare (TSH).

On the pre-established evaluation dates, 15 plants per plot were randomly collected and submitted to laboratory analyses to determine shikimic and salicylic acids. The leaves were dried in air circulation oven at $60{ }^{\circ} \mathrm{C}$ for 72 hours. Then, they were ground in a Wiley cutting mill.

For analysis of shikimic acid (SkA) and Salicylic acid (SA), $400 \mathrm{mg}$ of each sample was weighed and then added to $10 \mathrm{~mL}$ of water with pH 7.0 in a $50 \mathrm{~mL}$ glass bicker. Next, each bicker was placed in the center of a microwave oven (Panasonic Model $\mathrm{NN}-\mathrm{S} 62 \mathrm{~B})$ for $20 \mathrm{~s}$ at $100 \mathrm{~W}$ and the average temperature of $49.8^{\circ} \mathrm{C}\left( \pm 2.8^{\circ} \mathrm{C}\right)$, according to Matallo et al. (2009). After cooling, the sample was filtered in Whatmann Grade 1 paper filter and Millex - GV syringe filter (Millipore).

The analyses were carried out in a liquid chromatographer and mass spectrometer (LCMS), Shimadzu, with the following features: LC-20AD pump; SIL-10AF injector, CTO-10AS up oven, CBM-20 A controller, DGU-20A5 degasser, and LCMS2010 EV mass spectrometer. The analytical method utilized Gemini (Phenomenex) C18 column, particle size of $5 \mathrm{~nm}, 150 \mathrm{x} 4.6$ mm dimensions, movable phase A: water with $0.5 \%$ acetic acid, phase B: methanol and $0.5 \%$ of acetic acid, $0.4 \mathrm{~L}$ min- $1 \mathrm{flow}$, oven temperature at $30^{\circ} \mathrm{C}$, ionizing type in negative mode, $\mathrm{m} / \mathrm{z}$ shikimic acid: $173, \mathrm{~m} / \mathrm{z}$ salicylic acid: 137 , equipment tuning condition done by its own routine utilizing polyethylene glycol as standard.

Total time of 20 minutes was determined for the acid race. The retention time of shikimic acid was 5 minutes $( \pm 0.1)$, and of Salicylic acid, it was 19 minutes ( \pm 0.1$)$ according to Matallo et al. (2009).

The statistical analyses were done by Assistant (SILVA and AZEVEDO, 2016). The averages were compared by Tukey's test at $5 \%$ of probability, according to (BANZATO and KRONKA, 2006).

\section{RESULTS AND DISCUSSION}

As shown in Table 1, there was significant difference and interaction among the factors for technological variables of Brix $(\%$ juice), pol (\% juice), reducing sugars (RS\%), total reducing sugars (TRS \%) in sugarcane variety when different chemical ripeners were utilized in the evaluated crop years. There was a significant difference among most factors regardless of the technological characteristics as well as for all interactions among them. 
Citation: Ronaldo da Silva Viana, et al., Productivity and Biochemical Characteristics of Sugarcane When Submitted to the Action of Chemical Ripeners. Australian Journal of Basic and Applied Sciences, 13(2): 64-71. DOI: 10.22587/ajbas.2019.13.2.9

Table 1. Evaluations of technological parameters Brix (\% juice), Pol (\% juice) Reducing Sugars (RS\%) and Total Reducing Sugars (TRS\%) of sugarcane submitted to application of mixtures of chemical ripeners at different harvest times and crop years.

\begin{tabular}{|c|c|c|c|c|}
\hline Variation causes & $\begin{array}{c}\text { Brix } \\
\text { (\% juice) }\end{array}$ & $\begin{array}{c}\text { Pol } \\
\text { (\% juice) }\end{array}$ & $(\mathrm{RS} \%)$ & $(\mathrm{TRS} \%)$ \\
\hline \multicolumn{5}{|c|}{ Ripeners (R) } \\
\hline Control & $13.26 \mathrm{~d}$ & $10.35 \mathrm{c}$ & $0.83 \mathrm{a}$ & $11.74 \mathrm{c}$ \\
\hline $\mathrm{SG}$ & $14.81 b$ & $12.31 b$ & $0.67 b$ & $13.64 b$ \\
\hline $\mathrm{EG}$ & $13.73 \mathrm{~cd}$ & $11.65 b$ & $0.72 b$ & $12.99 b$ \\
\hline $\mathrm{G}$ & $14.37 \mathrm{bc}$ & $12.32 b$ & $0.70 b$ & $13.67 b$ \\
\hline $\mathrm{CG}$ & $16.40 \mathrm{a}$ & $13.94 a$ & $0.58 \mathrm{c}$ & $15.26 \mathrm{a}$ \\
\hline MSD & 0.93 & 0.99 & 0.07 & 0.97 \\
\hline $\mathrm{CV} \%$ & 5.85 & $7.47^{-1}$ & 9.78 & 6.61 \\
\hline $\mathrm{F}(\mathrm{R})$ & $36.43 * *$ & $36.96 * *$ & $30.77 * *$ & $37.07 * *$ \\
\hline \multicolumn{5}{|c|}{ Sampling times $(\mathrm{S})$} \\
\hline 0 daa & $14.26 \mathrm{~b}$ & $11.84 \mathrm{~b}$ & $0.72 \mathrm{a}$ & $13.19 b$ \\
\hline 15 daa & $14.32 \mathrm{~b}$ & $12.00 \mathrm{~b}$ & $0.71 \mathrm{a}$ & $13.35 b$ \\
\hline 30 daa & $14.95 \mathrm{a}$ & $12.51 \mathrm{a}$ & $0.67 b$ & $13.84 a$ \\
\hline MSD & 0.47 & 0.44 & 0.03 & 0.43 \\
\hline CV\% & 5.03 & 5.68 & 8.66 & 4.95 \\
\hline $\mathrm{F}(\mathrm{T})$ & $8.35 * *$ & $7.76^{* *}$ & $6.08 * *$ & $7.86^{* *}$ \\
\hline \multicolumn{5}{|c|}{ Year $(\mathrm{Y})$} \\
\hline 2008 & $14.46 \mathrm{a}$ & $12.06 \mathrm{a}$ & $0.70 \mathrm{a}$ & $13.41 \mathrm{a}$ \\
\hline 2009 & $14.57 \mathrm{a}$ & $12.17 \mathrm{a}$ & $0.70 \mathrm{a}$ & $13.51 \mathrm{a}$ \\
\hline MSD & 0.30 & 0.29 & 0.02 & 0.29 \\
\hline $\mathrm{CV} \%$ & 4.88 & 5.71 & 7.64 & 5.08 \\
\hline $\mathrm{F}(\mathrm{Y})$ & $0.54 \mathrm{~ns}$ & $0.55 \mathrm{~ns}$ & $0.41 \mathrm{~ns}$ & $0.55 \mathrm{~ns}$ \\
\hline MxT & $13.11 * *$ & $8.44 * *$ & $5.53 *$ & $8.68 * *$ \\
\hline $\mathrm{VxY}$ & $9.56 * *$ & $6.95 * *$ & $7.05 * *$ & $6.76^{* *}$ \\
\hline ExY & $7.52 * *$ & $5.37 *$ & $5.44 * *$ & $5.24 *$ \\
\hline $\mathrm{MxSxY}$ & $7.08 * *$ & $6.77 * *$ & $5.83 * *$ & $6.67 * *$ \\
\hline
\end{tabular}

Small letters compare averages in the column. Letters that are the same do not differ among themselves by Tukey's test at $5 \%$ probability within the same factor, $* *$ significant at $1 \%$ of probability $(\mathrm{p}<0.01), *$ significant at $5 \%$ of probability $(0.01=<\mathrm{p}<0.05)$, ns - non-significant ( $\mathrm{p}>=0.05)$, daa - days after application, MSD - minimum significant difference, $(\mathrm{R})$ - ripener, $(\mathrm{T})$ - sampling time, (Y) - year, C - control, SG - sulfomethuron methyl + glyphosate, EG - ethephon + glyphosate, G - glyphosate, CG compounds of organic carboxylic radicals + glyphosate

Table 2 shows the average values regarding the outcomes of a significant interaction of sugarcane between the mixtures of chemical ripeners and different sampling times and different crop years for brix (\% juice) and pol (\% juice).

Table 2. Average values regarding the outcomes of a significant interaction of sugarcane between the mixtures of chemical ripeners and different sampling times and different crop years for brix (\% juice) and pol (\% juice).

\begin{tabular}{cccccc}
\hline & $\begin{array}{c}\text { Sampling } \\
\text { times }\end{array}$ & \multicolumn{2}{c}{ Brix (\% juice) } & \multicolumn{2}{c}{ Pol (\% juice) } \\
Ripeners & daa & 2008 & 2009 & 2008 & 2009 \\
\hline \multirow{2}{*}{$\mathrm{C}$} & 0 & $11.94 \mathrm{~B}$ & $13.57 \mathrm{~A}$ & $8.83 \mathrm{~B}$ & $10.69 \mathrm{~A}$ \\
& 15 & $13.54 \mathrm{~A}$ & $13.59 \mathrm{~A}$ & $10.64 \mathrm{~A}$ & $10.90 \mathrm{~A}$ \\
& 30 & $13.74 \mathrm{~A}$ & $13.15 \mathrm{~A}$ & $10.91 \mathrm{~A}$ & $10.16 \mathrm{~A}$ \\
\hline \multirow{2}{*}{$\mathrm{SG}$} & 0 & $15.09 \mathrm{~A}$ & $14.34 \mathrm{~A}$ & $12.81 \mathrm{~A}$ & $11.61 \mathrm{~B}$ \\
& 15 & $14.82 \mathrm{~A}$ & $14.83 \mathrm{~A}$ & $12.26 \mathrm{~A}$ & $12.26 \mathrm{~A}$ \\
& 30 & $13.95 \mathrm{~B}$ & $15.81 \mathrm{~A}$ & $13.35 \mathrm{~B}$ & $13.59 \mathrm{~A}$ \\
\hline \multirow{2}{*}{$\mathrm{EG}$} & 0 & $15.10 \mathrm{~A}$ & $14.74 \mathrm{~A}$ & $12.72 \mathrm{~A}$ & $12.10 \mathrm{~A}$ \\
& 15 & $15.37 \mathrm{~A}$ & $11,34 \mathrm{~B}$ & $13,06 \mathrm{~A}$ & $9,85 \mathrm{~B}$ \\
& 30 & $12.42 \mathrm{~A}$ & $13,40 \mathrm{~A}$ & $10,67 \mathrm{~A}$ & $11,52 \mathrm{~A}$ \\
\hline \multirow{2}{*}{$\mathrm{G}$} & 0 & $13.91 \mathrm{~A}$ & $14,67 \mathrm{~A}$ & $12,00 \mathrm{~A}$ & $12,54 \mathrm{~A}$ \\
& 15 & $12.23 \mathrm{~B}$ & $14,77 \mathrm{~A}$ & $10,55 \mathrm{~B}$ & $12,68 \mathrm{~A}$ \\
& 30 & $14.65 \mathrm{~B}$ & $16,00 \mathrm{~A}$ & $12,59 \mathrm{~A}$ & $13,58 \mathrm{~A}$ \\
\hline \multirow{2}{*}{$\mathrm{CG}$} & 0 & $15.24 \mathrm{~A}$ & $13,99 \mathrm{~B}$ & $13,04 \mathrm{~A}$ & $12,08 \mathrm{~A}$ \\
& 15 & $17.00 \mathrm{~A}$ & $15,71 \mathrm{~B}$ & $14,40 \mathrm{~A}$ & $13,41 \mathrm{~A}$ \\
-----------------10 & $17.85 \mathrm{~A}$ & $18,59 \mathrm{~A}$ & $15,12 \mathrm{~A}$ & $15,62 \mathrm{~A}$ \\
\hline
\end{tabular}


Citation: Ronaldo da Silva Viana, et al., Productivity and Biochemical Characteristics of Sugarcane When Submitted to the Action of Chemical Ripeners. Australian Journal of Basic and Applied Sciences, 13(2): 64-71. DOI: 10.22587/ajbas.2019.13.2.9

Capital letters that are the same do not differ among themselves by Tukey's test at 5\% probability, daa - days after application, MSD - minimum significant difference, $\mathrm{C}$ - control, SG - sulfomethuron methyl + glyphosate, EG - ethephon + glyphosate, $\mathrm{G}-$ glyphosate, $\mathrm{CG}$ - compounds of organic carboxylic radicals + glyphosate

A significant effect among the treatments was found for brix (\% juice) and pol (\% juice), mainly with CG at 30 daa in years 2008 and 2009. The utilization of chemical ripeners is an important tool because the products are applied to anticipate the maturation process, promote enhancement in raw material quality and help crop planning (CAPUTO et al., 2008). Similarly, the use of chemical ripeners in this study enhanced the technological quality of sweet sorghum. Similar results were observed by Viana et al. (2008) in sugarcane crop, where G and CG induced an increase in sucrose of all sections of the sugarcane stalk due to physiological stress.

According to Prasad et al. (2007), the ideal harvest stage of sugarcane occurs when juice presents brix ranging from 15.5 to $16.5^{\circ}$, which is an important level to obtain juice that has high fermentation quality and consequently maximizes ethanol production per hectare. Silva et al. (2010) observed ripening anticipation and an increment in pol content when there was an application of SG. Those authors also pointed out that the mixture of sulfomethuron methyl and ethyl-trinexapac to glyphosate, in general, provided similar results to ripeners when applied separately.

Table 3 presents the average values regarding the outcomes of significant interaction for sugarcane between the mixtures of chemical ripeners and different sampling times and different crop years for the technological characteristics of Reducing Sugars (RS\%) and Total Reducing Sugars (TRS\%).

Table 3. Average values regarding the outcomes of significant interaction for sugarcane between the mixtures of chemical ripeners and different sampling times and different crop years for the technological characteristics of Reducing Sugars (RS\%) and Total Reducing Sugars (TRS\%).

\begin{tabular}{|c|c|c|c|c|c|}
\hline & Sampling times & \multicolumn{2}{|c|}{$\mathrm{RS} \%$} & \multicolumn{2}{|c|}{ TRS $\%$} \\
\hline Ripeners & daa & 2008 & 2009 & 2008 & 2009 \\
\hline \multirow{3}{*}{$\mathrm{C}$} & 0 & $0.95 \mathrm{~A}$ & $0,81 \mathrm{~B}$ & $10,26 \mathrm{~B}$ & $12,0 \mathrm{~A}$ \\
\hline & 15 & $0.82 \mathrm{~A}$ & $0,77 \mathrm{~A}$ & $12,02 \mathrm{~A}$ & $12,25 \mathrm{~A}$ \\
\hline & 30 & $0.79 \mathrm{~A}$ & $0,85 \mathrm{~A}$ & $12,28 \mathrm{~A}$ & $11,55 \mathrm{~A}$ \\
\hline \multirow{3}{*}{ SG } & 0 & $0.62 \mathrm{~B}$ & $0,74 \mathrm{~A}$ & $14,11 \mathrm{~A}$ & $12,97 \mathrm{~A}$ \\
\hline & 15 & $0.68 \mathrm{~A}$ & $0,69 \mathrm{~A}$ & $13,59 \mathrm{~A}$ & $13,60 \mathrm{~A}$ \\
\hline & 30 & $0.73 \mathrm{~A}$ & $0,58 \mathrm{~B}$ & $12,68 \mathrm{~B}$ & $14,89 \mathrm{~A}$ \\
\hline \multirow{3}{*}{ EG } & 0 & $0.64 \mathrm{~A}$ & $0,71 \mathrm{~A}$ & $14,03 \mathrm{~A}$ & $13,45 \mathrm{~A}$ \\
\hline & 15 & $0.62 \mathrm{~B}$ & $0,83 \mathrm{~A}$ & $14,37 \mathrm{~A}$ & $11,21 \mathrm{~B}$ \\
\hline & 30 & $0.79 \mathrm{~A}$ & $0,73 \mathrm{~A}$ & $12,03 \mathrm{~A}$ & $12,87 \mathrm{~A}$ \\
\hline \multirow{3}{*}{ G } & 0 & $0.73 \mathrm{~A}$ & $0,68 \mathrm{~A}$ & $13,37 \mathrm{~A}$ & $13,88 \mathrm{~A}$ \\
\hline & 15 & $0.82 \mathrm{~A}$ & $0,68 \mathrm{~B}$ & $11,93 \mathrm{~B}$ & $14,03 \mathrm{~A}$ \\
\hline & 30 & $0.69 \mathrm{~A}$ & $0,58 \mathrm{~B}$ & $13,95 \mathrm{~A}$ & $14,88 \mathrm{~A}$ \\
\hline \multirow{3}{*}{$\mathrm{CG}$} & 0 & $0.61 \mathrm{~B}$ & $0,72 \mathrm{~A}$ & $14,34 \mathrm{~A}$ & $13,44 \mathrm{~A}$ \\
\hline & 15 & $0.58 \mathrm{~A}$ & $0,63 \mathrm{~A}$ & $15,74 \mathrm{~A}$ & $14,75 \mathrm{~A}$ \\
\hline & 30 & $0.50 \mathrm{~A}$ & $0,45 \mathrm{~A}$ & $16,42 \mathrm{~A}$ & $16,90 \mathrm{~A}$ \\
\hline
\end{tabular}

Capital letters in the same line do not differ among themselves by Tukey's test at 5\% probability, daa - days after application, MSD - minimum significant difference, C - control, SG - sulfomethuron methyl + glyphosate, EG - ethephon + glyphosate, G glyphosate, $\mathrm{CG}$ - compounds of organic carboxylic radicals + glyphosate

In addition, there was an increase in Reducing Sugars content for the control treatment, as shown in Table 3. When ripeners were utilized, there was a decrease in the average values of Reducing Sugars. As times to collect material passed by, the values for that characteristic gradually decreased. The increase in Reducing Sugars favors plant growth and directly affects its purity, showing a smaller efficiency of the industry to recover sucrose. On the other hand, its reduction favors sugarcane ripening. The same was observed in the study by Viana et al. (2008) where the values decreased significantly as time passed by, reaching low values at 71 daa.

The greatest values for Total Reducing Sugars (TRS\%) again occurred when CG was applied as shown in Table 3. For this characteristic, it was verified that the best sampling time was at 30 daa. The increase in Reducing Sugar content favors plant growth and directly affects juice purity, resulting in lower efficiency recovery of sucrose by the industry. On the other hand, the reduction of these carbohydrates enhances the technological quality of the juice, favoring sugarcane ripening (LEITE et al., 2009a; ROBERTO et al., 2015).

According to data presented in Table 4, a significant interaction was observed in the results for fiber (\%), purity (\%), humidity $(\%)$ and TRS $\left(\mathrm{kg} \mathrm{t}^{-1}\right)$. There was a significant difference among most of the technological characteristics separately as well as for all their interactions. 
Citation: Ronaldo da Silva Viana, et al., Productivity and Biochemical Characteristics of Sugarcane When Submitted to the Action of Chemical Ripeners. Australian Journal of Basic and Applied Sciences, 13(2): 64-71. DOI: 10.22587/ajbas.2019.13.2.9

Table 4. Average values regarding the outcomes of significant sugarcane interaction between mixtures of chemical ripeners and different sampling times and different crop years for fiber (\%); Purity (\%); humidity (\%) and TRS (kg t $\left.{ }^{-1}\right)$.

\begin{tabular}{|c|c|c|c|c|}
\hline Variation causes & $\begin{array}{c}\text { fiber } \\
(\%)\end{array}$ & $\begin{array}{c}\text { purity } \\
(\%)\end{array}$ & $\begin{array}{c}\text { humidity } \\
(\%)\end{array}$ & $\begin{array}{c}\text { TRS } \\
\left(\mathrm{kg} \mathrm{t}^{-1}\right)\end{array}$ \\
\hline \multicolumn{5}{|c|}{ Ripeners (R) } \\
\hline Control & $10.78 \mathrm{c}$ & $77.96 \mathrm{c}$ & $75.95 a$ & $106.25 \mathrm{c}$ \\
\hline SG & $11.41 \mathrm{ab}$ & $83.07 \mathrm{~b}$ & $73.77 b$ & $123.47 \mathrm{~b}$ \\
\hline EG & $11.07 \mathrm{bc}$ & $81.57 \mathrm{~b}$ & $74.67 \mathrm{~b}$ & $117.61 \mathrm{~b}$ \\
\hline $\mathrm{G}$ & $11.25 \mathrm{ab}$ & $82.29 b$ & $73.79 b$ & $123.78 b$ \\
\hline $\mathrm{CG}$ & $11.71 \mathrm{a}$ & $86.09^{a}$ & $72.12 \mathrm{c}$ & $138.18 \mathrm{a}$ \\
\hline MSD & 0.45 & 2.39 & 1.22 & 8.84 \\
\hline $\mathrm{CV} \%$ & 3.70 & 2.65 & 1.51 & 6.61 \\
\hline $\mathrm{F}(\mathrm{R})$ & $12.68 * *$ & $32.39 * *$ & $28.43 * *$ & $37.07 * *$ \\
\hline \multicolumn{5}{|c|}{ Sampling times $(\mathrm{T})$} \\
\hline 0 daa & $11.11 b$ & $81.58 \mathrm{~b}$ & $74.40 \mathrm{a}$ & $119.41 b$ \\
\hline 15 daa & $11.20 \mathrm{~b}$ & $81.81 b$ & $74.17 \mathrm{a}$ & $120.84 b$ \\
\hline 30 daa & $11.42 \mathrm{a}$ & $83.21 \mathrm{a}$ & $73.61 \mathrm{~b}$ & $125.33 \mathrm{a}$ \\
\hline MSD & 0.20 & 1.35 & 0.42 & 3.94 \\
\hline CV\% & 2.85 & 2.51 & 0.88 & 4.95 \\
\hline $\mathrm{F}(\mathrm{T})$ & $7.22 * *$ & $5.49 *$ & $11.91 * *$ & $7.86^{* *}$ \\
\hline \multicolumn{5}{|c|}{ Year $(\mathrm{Y})$} \\
\hline 2008 & $11.23 \mathrm{a}$ & $82.08 \mathrm{a}$ & $74.12 \mathrm{a}$ & $121.67 \mathrm{a}$ \\
\hline 2009 & $11.26 \mathrm{a}$ & $82.32 \mathrm{a}$ & $74.00 \mathrm{a}$ & $122.34 \mathrm{a}$ \\
\hline MSD & 0.19 & 0.76 & 0.29 & 2.66 \\
\hline $\mathrm{CV} \%$ & 3.94 & 2.17 & 0.94 & 5.08 \\
\hline $\mathrm{F}(\mathrm{Y})$ & $0.10 \mathrm{~ns}$ & $0.42 \mathrm{~ns}$ & $0.75 \mathrm{~ns}$ & $0.55 \mathrm{~ns}$ \\
\hline $\mathrm{VxR}$ & $3.52 *$ & $5.27 * *$ & $10.54 * *$ & $8.68^{* *}$ \\
\hline $\mathrm{VxT}$ & $2.21 \mathrm{~ns}$ & $6.59 * *$ & $9.04 * *$ & $6.76 * *$ \\
\hline $\mathrm{MxT}$ & $4.98 * *$ & $4.92 *$ & $10.11 * *$ & $5.24 *$ \\
\hline $\mathrm{VxMxT}$ & $0.88 \mathrm{~ns}$ & $5.75^{*} *$ & $6.90 * *$ & $6.67 * *$ \\
\hline
\end{tabular}

Small letters compare averages in the column. Letters that are the same do not differ among themselves by Tukey's test at $5 \%$ probability within the same factor, $* *$ significant at $1 \%$ of probability $(\mathrm{p}<0.01), *$ significant at $5 \%$ of probability $(0.01=<\mathrm{p}<0.05)$, ns - non-significant ( $\mathrm{p}>=0.05)$, daa - days after application, MSD - minimum significant difference, $(\mathrm{R})$ - ripener, $(\mathrm{T})$ - sampling time, (Y) - year, C - control, SG - sulfomethuron methyl + glyphosate, EG - ethephon + glyphosate, G - glyphosate, CG compounds of organic carboxylic radicals + glyphosate

The average values related to the outcomes of significant interactions between the mixtures of chemical ripeners and different sampling times of sugarcane stalks for fiber $(\%)$ are shown in Table 5.

Table 5. Average values related to the outcomes of significant interactions between the mixtures of chemical ripeners and different sampling times of sugarcane stalks for fiber $(\%)$.

\begin{tabular}{|c|c|c|c|}
\hline \multirow[b]{2}{*}{ Ripeners } & \multicolumn{3}{|c|}{ Sampling times } \\
\hline & 0 daa & 15 daa & 30 daa \\
\hline \multicolumn{4}{|c|}{ Fiber $(\%)$} \\
\hline $\mathrm{C}$ & $10.76 \mathrm{aA}$ & $10.74 \mathrm{cA}$ & $10,84 \mathrm{cA}$ \\
\hline EG & $11.28 \mathrm{aA}$ & $11.52 \mathrm{abA}$ & $11,42 \mathrm{bcA}$ \\
\hline SG & $11.18 \mathrm{aA}$ & $10.90 \mathrm{cA}$ & $11,12 \mathrm{bcA}$ \\
\hline $\mathrm{G}$ & $11.19 \mathrm{aA}$ & $11.07 \mathrm{bcA}$ & $11,51 \mathrm{bA}$ \\
\hline $\mathrm{CG}$ & $11.15 \mathrm{aB}$ & $11.77 \mathrm{aA}$ & $12,20 \mathrm{aA}$ \\
\hline MSD & \multicolumn{2}{|c|}{ Col.: 0.59} & .46 \\
\hline
\end{tabular}

Small letters compare averages in the column. Capital letters compare averages in the line. Letters that are the same do not differ among themselves by Tukey's test at $5 \%$ probability, daa - days after application, MSD - minimum significant difference, C control, SG - sulfomethuron methyl + glyphosate, EG - ethephon + glyphosate, G - glyphosate, CG - compounds of organic carboxylic radicals + glyphosate

For Fiber, the CG treatment presented greater values as samplings were done at different times. The increase in fiber content due to the application of chemical ripeners had already been observed by Viana et al. (2008); Leite and Crusciol (2008). However, Caputo et al. (2008) and Leite et al. (2009c) did not observe significant alterations in fiber content when ripeners without mixtures were applied. Leite et al. (2009b) verified that there was an increase in fiber content in some sugarcane varieties when ripeners were utilized.

Table 6 shows the average values related to the results of significant interaction between different sampling times of sugarcane stalks and crop years for fiber $(\%)$. 
Citation: Ronaldo da Silva Viana, et al., Productivity and Biochemical Characteristics of Sugarcane When Submitted to the Action of Chemical Ripeners. Australian Journal of Basic and Applied Sciences, 13(2): 64-71. DOI: 10.22587/ajbas.2019.13.2.9

Table 6. Average values related to the results of significant interaction between different sampling times of sugarcane stalks and crop years for fiber $(\%)$.

\begin{tabular}{|c|c|c|}
\hline & \multicolumn{2}{|c|}{ Year } \\
\hline Sampling times & 2008 & 2009 \\
\hline & \multicolumn{2}{|c|}{ Fiber $(\%)$} \\
\hline 0 daa & $11.14 \mathrm{aA}$ & $11.08 \mathrm{bA}$ \\
\hline 15 daa & $11.34 \mathrm{aA}$ & $11.06 \mathrm{bA}$ \\
\hline 30 daa & $11.20 \mathrm{aB}$ & $11.63 \mathrm{aA}$ \\
\hline MSD & Col.: 0.34 & Lin: 0.33 \\
\hline
\end{tabular}

Small letters compare averages in the column. Capital letters compare averages in the line. Letters that are the same do not differ among themselves by Tukey's test at 5\% probability, daa - days after application, MSD - minimum significant difference, C control, SG - sulfomethuron methyl + glyphosate, EG - ethephon + glyphosate, G - glyphosate, CG - compounds of organic carboxylic radicals + glyphosate

An increase in the average values of fiber (\%) was verified at 15 daa in the crop year of 2008 and at 30 daa in 2009. According to Viana et al. (2008), fiber content over 14\% reduces the efficiency of juice extraction in the mill; however, sug arcane varieties with fiber content below $10 \%$ are more susceptible to mechanical damages caused by cutting and loading, resulting in sugar losses due to contamination by microorganisms that have access to the internal part of stalks. The fiber content increa se due to the application of chemical ripeners has already been observed by other authors such as Leite et al. (2009b). However, Caputo et al. (2008) did not verify significant alterations in fiber content with application of ripeners.

Table 7 presents the averages related to the outcomes of significant interaction between mixtures of chemical ripeners and different sampling times and different crop years in sugarcane variety for purity (\%); humidity (\%) and TRS (kg t $\left.\mathrm{t}^{-1}\right)$.

Table 7. Averages related to the outcomes of significant interaction between mixtures of chemical ripeners and different sampling times and different crop years in sugarcane variety for purity $(\%)$; humidity (\%) and TRS $\left(\mathrm{kg} \mathrm{t}^{-1}\right)$.

\begin{tabular}{|c|c|c|c|c|c|c|c|}
\hline & Sampling times & \multicolumn{2}{|c|}{ purity $(\%)$} & \multicolumn{2}{|c|}{ humidity (\%) } & \multicolumn{2}{|c|}{$\operatorname{TRS}\left(\mathrm{kg} \mathrm{t}^{-1}\right)$} \\
\hline Ripeners & daa & 2008 & 2009 & 2008 & 2009 & 2008 & 2009 \\
\hline \multirow{3}{*}{$\mathrm{C}$} & 0 & $73.93 \mathrm{~B}$ & $78.71 \mathrm{~A}$ & $77.38 \mathrm{~A}$ & $75.56 \mathrm{~B}$ & $92.87 \mathrm{~B}$ & 109.19A \\
\hline & 15 & $78.47 \mathrm{~A}$ & $80.07 \mathrm{~A}$ & $75.65 \mathrm{~A}$ & $75.72 \mathrm{~A}$ & $108.81 \mathrm{~A}$ & $110.89 \mathrm{~A}$ \\
\hline & 30 & $79.34 \mathrm{~A}$ & $77.26 \mathrm{~A}$ & $75.47 \mathrm{~A}$ & $75.93 \mathrm{~A}$ & $111.15 \mathrm{~A}$ & $104.60 \mathrm{~A}$ \\
\hline \multirow{3}{*}{ SG } & 0 & $84.90 \mathrm{~A}$ & $80.95 \mathrm{~B}$ & $73.40 \mathrm{~B}$ & $74.59 \mathrm{~A}$ & $127.72 \mathrm{~A}$ & $117.42 \mathrm{~A}$ \\
\hline & 15 & $82.73 \mathrm{~A}$ & $82,53 \mathrm{~A}$ & $73,47 \mathrm{~A}$ & $73,81 \mathrm{~A}$ & $123,02 \mathrm{~A}$ & $123,09 \mathrm{~A}$ \\
\hline & 30 & 81.40B & $85,92 \mathrm{~A}$ & $75,06 \mathrm{~A}$ & $72,3 \mathrm{~B}$ & $114,81 \mathrm{~B}$ & $134,79 \mathrm{~A}$ \\
\hline \multirow{3}{*}{$\mathrm{EG}$} & 0 & $84.24 \mathrm{~A}$ & $82,04 \mathrm{~A}$ & $73,72 \mathrm{~A}$ & $74,06 \mathrm{~A}$ & $127,01 \mathrm{~A}$ & $121,72 \mathrm{~A}$ \\
\hline & 15 & $84.92 \mathrm{~A}$ & $77,99 \mathrm{~B}$ & $73,32 \mathrm{~B}$ & $76,85 \mathrm{~A}$ & $130,06 \mathrm{~A}$ & $101,49 B$ \\
\hline & 30 & $79.08 \mathrm{~A}$ & $81,17 \mathrm{~A}$ & $75,34 \mathrm{~A}$ & $74,72 \mathrm{~A}$ & $108,93 \mathrm{~A}$ & $116,48 \mathrm{~A}$ \\
\hline \multirow{3}{*}{ G } & 0 & $81.37 \mathrm{~A}$ & $82,85 \mathrm{~A}$ & $74,35 \mathrm{~A}$ & $73,40 \mathrm{~A}$ & $121,01 \mathrm{~A}$ & $125,66 \mathrm{~A}$ \\
\hline & 15 & $78.15 B$ & $82,75 \mathrm{~A}$ & $75,58 \mathrm{~A}$ & $73,45 \mathrm{~B}$ & $108,02 B$ & $127,03 \mathrm{~A}$ \\
\hline & 30 & 78.61B & $86,03 \mathrm{~A}$ & $73,60 \mathrm{~A}$ & $72,33 \mathrm{~B}$ & $126,28 \mathrm{~A}$ & $134,66 \mathrm{~A}$ \\
\hline \multirow{3}{*}{$\mathrm{CG}$} & 0 & $81.15 \mathrm{~A}$ & $81,63 \mathrm{~B}$ & $73,26 \mathrm{~A}$ & $74,32 \mathrm{~A}$ & $129,81 \mathrm{~A}$ & $121,64 \mathrm{~A}$ \\
\hline & 15 & $86.01 \mathrm{~A}$ & $84,74 \mathrm{~A}$ & $71,25 \mathrm{~B}$ & $72,57 \mathrm{~A}$ & $142,48 \mathrm{~A}$ & $133,54 \mathrm{~A}$ \\
\hline & 30 & $88.85 \mathrm{~A}$ & $90,45 \mathrm{~A}$ & $71,00 \mathrm{~A}$ & $70,30 \mathrm{~A}$ & $148,62 \mathrm{~A}$ & $152,97 \mathrm{~A}$ \\
\hline \multicolumn{2}{|r|}{$\mathrm{MSD}$} & \multicolumn{2}{|c|}{ Lin.: 2,97} & \multicolumn{2}{|c|}{ Lin.: 1.15} & \multicolumn{2}{|c|}{ Lin.: 10,33} \\
\hline
\end{tabular}

Capital letters in the same line do not differ among themselves by Tukey's test at 5\% probability, daa - days after application, MSD - minimum significant difference, C - control, SG - sulfomethuron methyl + glyphosate, EG - ethephon + glyphosate, G glyphosate, $\mathrm{CG}$ - compounds of organic carboxylic radicals + glyphosate

Regarding purity $(\%)$, an increase in the average values was verified when CG treatment was utilized at 30 daa in the crop years of 2008 and 2009. It is known that juice purity is correlated to the sugarcane ripening process and the minimum recommended levels are $80 \%$ for the initial crop and 85\% throughout the cultivation (LEITE and CRUSCIOL, 2008). These results corroborate the ones by Viana et al. (2008), who also found greater purity values after the application of SC.

Leite et al. (2009c) observed that when applied separately, sulfometuron methyl and glyphosate increase sugarcane juice purity significantly. The results corroborate the ones by Caputo et al. (2007), who also found greater purity values after the application of sulfomethuron methyl.

Table 8. Average values of TCH and TSH agricultural productivity parameters and SkA and SA biochemical characteristics of sugarcane variety submitted to the application of chemical ripeners, different harvesting times and crop year.

\begin{tabular}{ccccc}
\hline Variation causes & \multirow{2}{*}{ TCH } & TAH & $\begin{array}{c}\text { SkA } \\
\left(\mu \mathrm{g} \mathrm{g}^{-1}\right)\end{array}$ & $\begin{array}{c}\text { SA } \\
\left(\mu \mathrm{g} \mathrm{g}^{-1}\right)\end{array}$ \\
\hline \multirow{2}{*}{ Control } & \multicolumn{2}{c}{ Ripeners (R) } \\
\hline
\end{tabular}


Citation: Ronaldo da Silva Viana, et al., Productivity and Biochemical Characteristics of Sugarcane When Submitted to the Action of Chemical Ripeners. Australian Journal of Basic and Applied Sciences, 13(2): 64-71. DOI: 10.22587/ajbas.2019.13.2.9

\begin{tabular}{|c|c|c|c|c|}
\hline SG & $121.43 \mathrm{a}$ & $17.57 \mathrm{a}$ & $1.31 \mathrm{c}$ & $3.30 \mathrm{~b}$ \\
\hline EG & $118.48 \mathrm{a}$ & $15.74 \mathrm{a}$ & $4.18 b$ & $3.18 b c$ \\
\hline $\mathrm{G}$ & $102.31 \mathrm{a}$ & $15.36 \mathrm{a}$ & $6.70 \mathrm{a}$ & $6.32 \mathrm{a}$ \\
\hline $\mathrm{CG}$ & $112.35 \mathrm{a}$ & $17.13 \mathrm{a}$ & $6.73 \mathrm{a}$ & $4.01 \mathrm{~b}$ \\
\hline MSD & 21.66 & 3.42 & 1.16 & 1.48 \\
\hline $\mathrm{CV} \%$ & 9.96 & 10.83 & 15.11 & 20.87 \\
\hline $\mathrm{F}(\mathrm{R})$ & $2.58 \mathrm{~ns}$ & $1.78 \mathrm{~ns}$ & $117.76^{* *}$ & $27.11 * *$ \\
\hline \multicolumn{5}{|c|}{ Year $(\mathrm{Y})$} \\
\hline 2008 & $113.98 \mathrm{a}$ & $16.23 \mathrm{a}$ & $3.88 \mathrm{a}$ & $3.98 \mathrm{a}$ \\
\hline 2009 & $114.65 \mathrm{a}$ & $16.97 \mathrm{a}$ & $4.20 \mathrm{a}$ & $3.47 \mathrm{~b}$ \\
\hline MSD & 5.43 & 0.91 & 0.58 & 0.48 \\
\hline $\mathrm{CV} \%$ & 5.84 & 6.80 & 17.90 & 15.89 \\
\hline $\mathrm{F}(\mathrm{Y})$ & $0.07 \mathrm{~ns}$ & $3.19 \mathrm{~ns}$ & $1.49 \mathrm{~ns}$ & $5.50 *$ \\
\hline $\mathrm{MxY}$ & $4.14 *$ & $1.36 \mathrm{~ns}$ & $14.55 * *$ & $34.90 * *$ \\
\hline
\end{tabular}

Small letters compare averages in the column. Letters that are the same do not differ among themselves by Tukey's test at $5 \%$ probability within the same factor, $* *$ significant at $1 \%$ of probability $(\mathrm{p}<0.01)$, *significant at $5 \%$ of probability $(0.01=<\mathrm{p}<0.05)$, ns - non-significant ( $\mathrm{p}>=0.05)$, daa - days after application, MSD - minimum significant difference, $(\mathrm{R})$ - ripener, $(\mathrm{T})$ - sampling time, (Y) - year, C - control, SG - sulfomethuron methyl + glyphosate, EG - ethephon + glyphosate, G - glyphosate, CG compounds of organic carboxylic radicals + glyphosate methyl.

According to Table 7, humidity $(\%)$ presented greater values in the control treatment. When ripeners were used, there was a reduction of average humidity values. As sampling times passed by, the values gradually decreased. These results confirmed the ones found by Silva et al. (2010) who verified humidity decrease during maturation and also observed that glyphosate and sulfomethuron methyl stood out as promoters of greater increases in TRS at harvest.

There was an increase in average values for Recoverable Theoretical Sugar when CG was utilized at 30 daa. According to Leite et al. (2009c), the total recoverable theoretical sugar (TRTS) is important for the sugar-energy industry to estimate the amount of sucrose in the raw material that can be recovered as crystal sugar. These results are similar to the ones found for brix, pol, and total reducing sugars, mainly the mixtures cited previously. Leite et al. (2009a) reported that the agronomical efficiency of ripeners depends on the application time, climatic condition, and genetic characteristic of the variety. Moreover, they have to be applied when the ripening condition is not favored such as in cases of application off the season or under climatic conditions that do not favor this process. Therefore, the genetic potential of varieties is explored regarding sucrose accumulation to improve the quality of ray material. This trend was also observed by Viana et al. (2017) who verified that there is a stabilization of RTS values in stalks as sugarcane ripens.

According to Table 8, the average values of TCH and TSH agricultural productivity parameters and SkA and SA biochemical characteristics of sugarcane variety submitted to the application of chemical ripeners, different harvest times and crop year.

The average values are shown in Table 9 regarding the results of significant interaction of parameters of Tons of Culms per Hectare (TCH) and the biochemical characteristics of the shikimic acid (SkA) and salicylic acid (SA) of sugarcane variety submitted to application of chemical ripeners, different harvest times and crop years.

Table 9. Average values are shown in Table 9 regarding the results of significant interaction of parameters of Tons of Culms per Hectare (TCH) and the biochemical characteristics of the shikimic acid (SkA) and salicylic acid (SA) of sugarcane variety submitted to application of chemical ripeners, different harvest times and crop years.

\begin{tabular}{lllllll}
\hline & TCH & \multicolumn{3}{c}{ SkA $\left(\mu \mathrm{g} \mathrm{g}^{-1}\right)$} & SA $\left(\mu \mathrm{g} \mathrm{g}^{-1}\right)$ \\
\cline { 2 - 7 } Ripeners & 2008 & 2009 & 2008 & 2009 & 2008 & 2009 \\
\hline C & $125.10 \mathrm{aA}$ & $108.90 \mathrm{aB}$ & $1.04 \mathrm{bA}$ & $1.55 \mathrm{bA}$ & $2.08 \mathrm{cA}$ & $1.54 \mathrm{bA}$ \\
SG & $116.13 \mathrm{abA}$ & $126.73 \mathrm{aA}$ & $1.16 \mathrm{bA}$ & $1.47 \mathrm{bA}$ & $1.69 \mathrm{cB}$ & $4.92 \mathrm{aA}$ \\
EG & $119.03 \mathrm{abA}$ & $117.93 \mathrm{aA}$ & $2.25 \mathrm{bB}$ & $6.11 \mathrm{aA}$ & $3.00 \mathrm{bcA}$ & $3.37 \mathrm{aA}$ \\
$\mathrm{G}$ & $96.86 \mathrm{bA}$ & $107.76 \mathrm{aA}$ & $7.11 \mathrm{aA}$ & $6.29 \mathrm{aA}$ & $8.68 \mathrm{aA}$ & $3.96 \mathrm{aB}$ \\
$\mathrm{CG}$ & $112.76 \mathrm{abA}$ & $111.93 \mathrm{aA}$ & $7.85 \mathrm{aA}$ & $5.61 \mathrm{aB}$ & $4.44 \mathrm{bA}$ & $3.57 \mathrm{aA}$ \\
\hline MSD & Col.: 23.38 & Lin.:12.14 & Col.: 1.64 & Lin.:1.31 & Col.: 1.70 & Lin.: 1.07 \\
\hline
\end{tabular}

Capital letters in the same line do not differ among themselves by Tukey's test at 5\% probability, daa - days after application, MSD - minimum significant difference, Col. - column, Lin - line, C - control, SG - sulfomethuron methyl + glyphosate, EG ethephon + glyphosate, $\mathrm{G}$ - glyphosate, $\mathrm{CG}$ - compounds of organic carboxylic radicals + glyphosate

It is possible to observe that the control treatment presented the best average values for TCH of the crop year of 2008 which did not occur in 2009. These results corroborated the ones by Silva et al. (2010) who verified that sulfomethuron-methyl and the control promoted the smallest decreases in productivity. Leite and Crusciol (2008) observed significant reductions in productivity in $\mathrm{G}$ treatment and $\mathrm{CG}$ treatments.

In Table 9, it is possible to observe that in the crop year of 2008 the plants treated with CG presented greater concentrations of shikimic acid, followed by G treatment. However, in the crop year of 2009, the control treatment and the one with SG presented smaller average values. 
These results corroborate the ones by Matallo et al., (2009), working with glyphosate and shikimic acid concentration in citrus observed that the plants that received glyphosate application always presented the greatest concentration of shikimic acid compared to control plants. High levels of shikimic acid, detected from the applications of glyphosate, were detected in sunflower, wheat, and millet (HENRY et al., 2007).

A greater concentration in the values of salicylic acid in sugarcane can be observed in sugarcane when submitted to $G$ application in the crop year of 2008, which did not occur in 2009. Thus, even if there is a decrease in salicylic acid biosynthesis, the plant has an alternative or secondary pathway for its synthesis, that is, the salicylic production depends on the plant metabolism and the stressing factors to which it is submitted.

\section{CONCLUSIONS}

The application of a mixture of compounds of organic carboxylic radicals + glyphosate presented better results for sugarcane technological characteristics at 30 days after application in the studied crop years.

The application of $0.35 \mathrm{~L} \mathrm{ha}^{-1}$ glyphosate favored an increase in the concentrations of shikimic and salicylic acids in the crop years of 2008 and 2009 .

\section{REFERENCES}

Banzato, D.A., Kronka, S.N. 2006. Experimentação agrícola. vol.III, Jaboticabal: FUNEP, 237p.

Caputo, M.M., Beauclair, E.G.F., Silva, M.A., Piedade, S. M. S. 2008. Resposta de genótipos de cana-de-açúcar à aplicação de indutores de maturação. Bragantia, 67(1), 15-23. http://dx.doi.org/10.1590/S0006-87052008000100002

Caputo, M.M., Silva, M.A., Beauclair, E.G.F., Gava, G.J.C. 2007. Acúmulo de sacarose, produtividade e florescimento de canade-açúcar sob reguladores vegetais. Asociación Interciencia, 32(12), 834-840.

CONSECANA - Conselho dos Produtores de Cana-de-açúcar, Açúcar, Álcool do Estado de São Paulo. 2006. Manual de instruções. 5, Piracicaba: Consecana, 112p.

Empresa Brasileira de Pesquisa Agropecuária - EMBRAPA. 2013. Sistema brasileiro de classificação de solos. III, Brasília, 353p.

Henry, W.B., Shaner, D.L., West, M.S. 2007. Shikimate accumulation in sunflower, wheat and proso millet after glyphosate application. Weed Science, 55(4), 1-5.

Leite, G.H.P., Crusciol, C.A.C. 2008. Reguladores vegetais no desenvolvimento e produtividade da cana-de-açúcar. Pesquisa Agropecuária Brasileira, 43(8), 995-1001. http://dx.doi.org/10.1590/S0100-204X2008000800007

Leite, G.H.P., Crusciol, C.A.C., Silva, M.A., Venturini Filho, W.G. 2009a. Qualidade tecnológica da cana-de-açúcar em função da aplicação de maturadores em meio de safra. Bragantia, 68(2), 527-534. http://dx.doi.org/10.1590/S000687052009000200028

Leite, G.H.P., Crusciol, C.A.C., Silva, M.A., Venturini Filho, W.G., Suriano, A. 2009b. Qualidade tecnológica, produtividade e margem de contribuição agrícola da cana-de-açúcar em função da aplicação de reguladores vegetais no início da safra. Ciência Rural, 39(3), 726-732. http://dx.doi.org/10.1590/S0103-84782009000300015

Leite, G.H.P. 2009c. Reguladores vegetais e atividade de invertases em cana-de-açúcar em meio de safra. Ciência Rural, 39(3), 718-725. http://dx.doi.org/10.1590/S0103-84782009000300014

Matallo, M.B., Almeida, S.D.B., Cerdeira, A.L., Franco, D.A., Blanco, F.M.G., Menezes, P. T.C., Luchini, L.C., Moura, M.A. M., Duke, S.O. 2009. Microwave-assisted solvent extraction and analysis of shikimic acid from plant tissues. Planta Daninha, 27, 987-994. http://dx.doi.org/10.1590/S0100-83582009000500012

Meschede, D.K., Velini, E.D., Tonin, F.G., Carbonari, C. 2012. Alterações no metabolismo da cana-de-açúcar em função da aplicação de maturadores. Planta Daninha, 30(1), 113-119. http://dx.doi.org/10.1590/S0100-83582012000100013

Prasad, S., Singh, A., Jain, N., Joshi, H.C. 2007. Ethanol production from sweet sorghum syrup for utilization as automotive fuel in India. Energy and Fuels, 21, 2415-2420. http://dx.doi.org/10.1021/ef060328z

Roberto, G.G., Cunha, C., Sales, C.R.G., Silveira, N.M., Ribeiro, R.V., Machado, E.C., Lagôa, A.M.M.A. 2015. Variation of photosynthesis and carbohydrate levels induced by ethephon and water deficit on the ripening stage of sugarcane. Bragantia, 74(4), 379-386. http://dx.doi.org/10.1590/1678-4499.0062

Silva, F.A.S., Azevedo, C.A.V. 2016. The Assistat Software Version 7.7 and its use in the analysis of experimental data. African Journal Agriculture Resarch, 11(39), 3733-3740. http://dx.doi.org/10.5897/AJAR2016.11522

Silva, M.A., Gava, G.J. C., Caputo, M.M., Sorrilla, P.F., Bassetto, S. C. 2010. Produtividade de colmos e de sacarose em cana-deaçúcar em função da interação entre cultivares e maturadores. Scientia Agraria, 11(4), $323-329$. http://dx.doi.org/10.5380/rsa.v11i4.1826

Viana, R.S., Silva, P.H., Mutton, M.A., Mutton, M.J.R., Guimarães, E.R., Bento, M. 2008. Efeito da aplicação de maturadores químicos na cultura da cana-de-açúcar (Saccharum spp.) variedade SP81-3250. Acta Scientiarum Agronomy, 30(1), 65-71. http://dx.doi.org/10.4025/actasciagron.v30i1.1130

Viana, R.S., Velini, E.D., Lisboa, L.A.M., Assumpção, A.C.N.D., Figueiredo, P.A.M. 2017. Application of chemical ripeners mixtures the technological quality and agricultural productivity of sugarcane. Revista Caatinga, 30(3), $541-550$. http://dx.doi.org/10.1590/1983-21252017v30n301rc 